\title{
PENGARUH PEMBELAJARAN MIND MAPPING KELAS VII PADA MATA PELAJARAN IPS TERHADAP KEMAMPUAN BERPIKIR KREATIF
}

\author{
Moh. Hadihabibi, Zainul Abidin, Arafah Husna \\ Jurusan Teknologi Pendidikan, Fakultas Ilmu Pendidikan, Universitas Negeri Malang \\ Jalan Semarang 5 Malang 65145 0341-574700 \\ Hadyhabibey55@gmail.com \\ Article History \\ Received: 2 November 2020, Accepted: 23 Desember 2020, Published: 28 Mei 2021
}

\begin{abstract}
Abstrak
Kemampuan siswa berpikir kreatif dapat ditingkatkan dengan menaikkan skor kemampuan siswa untuk memahami masalah, kefasihan, fleksibilitas dan kebaruan penyelesaian masalah. Hal tersebut selaras sama fungsi pemetaan pikiran yaitu sebuah teknik menulis materi yang dipelajari dan memprediksi permasalahan yang dihadapi dalam bentuk grafik sehingga mempermudah memahaminya. Tujuan penelitian adalah untuk melihat pengaruh model mind mapping terhadap kemampuan berpikir kreatif siswa pada mata pelajaran IPS. Jenis Penelitian yang diguunakan yaitu penelitian kuantitatif menggunakan quasi experimental design. Penelitian ini memakai Uji independent sample t test. Data diolah dengan berbantuan SPSS 20. Hasil pengolahan data, terdapat nilai sig (2tailed) sebesar 0,044<0,05, berarti hipotesis nihil (H0) ditolak. Sehingga ada perpedaan antara kelas eksperimen melebihi dari kelas kontrol. Kelas Eksperimen lebih unggul nilai rata-ratanya dengan kelas kontrol. Oleh karena itu terdapat pengaruh model pemetaan pikiran terhadap kemampuan berpikir kreatif anak didik pada mata pelajaran IPS dibanding kemampuan berpikir kreatif anak didik yang tidak memakai model pemetaan pikiran.
\end{abstract}

Keyword: Mind mapping; Kemamampuan berpikir keratif; Ilmu Pengetahuan

\begin{abstract}
Students 'ability to think creatively can be improved by increasing the score of students' ability to understand problems, fluency, flexibility and novelty in problem solving. This is in line with the mind mapping function, which is a technique of writing material that is studied and predicting the problems faced in graphical form so that it makes it easier to understand them. The research objective was to see the effect of themodel mind mapping on students' creative thinking abilities in social studies subjects. The type of research used is quantitative research using a quasi experimental design. This study uses independent sample t test. The data was processed with the help of SPSS 20. The results of data processing, there is a sig (2-tailed) value of $0.044<0.05$, meaning that the null hypothesis $(\mathrm{HO})$ is rejected. So that there is a difference between the experimental class more than the control class. The experimental class has the average score superior to the control class. Therefore there is an effect of the mind mapping model on students' creative thinking abilities in social studies subjects compared to the creative thinking abilities of students who do not use the mind mapping model.
\end{abstract}

Keyword: Put 3-5 your keywords here in Bahasa Indonesia; keywords separated by semicolon 


\section{PENDAHULUAN}

Masalah yang dihadapi terkait pendidikan di Indonesia sekarang yaitu melemahnya proses pembelajaran (Sanjaya, 2006). Dalam berlangsungnya pembelajaran pebelajar kurang adanya dorongan agar kemampuan berpikirnya menjadi berkembang. Pembelajaran di kelas biasanya diarahkan pada kemampuan pebelajar untuk mengingat informasi dari pertambahan bahan ajar yang didapatnya, otak siswa dipaksa supaya mengingat semua informasi tanpa harus memahaminya untuk dihubungkan dengan kehidupan kesehariannya. Hal itu menyebabkan pembelajaran tidak digunakan untuk mendorong dan mengembangkan sebuah karakter serta potensi pebelajar sebagai cara membentuk pribadi yang cerdas, mempunyai keterampilan dalam memecahkan persoalan hidup, dan tidak diberikan pengarahan untuk menciptakan individu yang aktif, kreatif dan inovatif. Hal tersebut berakibat ketika siswa selesai dari bangku sekolah, siswa menjadi pribadi yang pandai dalam teori, tetapi miskin dalam tindakan. Dalam permasalahan ini, peran guru sangat diperlukan untuk menciptakan suasana pembelajaran yang menyenangkan sehingga siswa menjadi lebih kreatif.

Ditinjau dari proses mengajar selama ini, biasanya guru hanya menjelasskan apa yang ada pada modul pembelajaran dan kurang membantu meningkatkann kemampuan siswa. Hal tersebut sama saja dengan pendidik tidak membagikan kesempatan kepada anak didik untuk memahami pengetahuan yang menjadi milik anak didik itu sendiri. Pendidik lebih memaksakan gaya berpikir anak didik dengan gaya berpikir yang dimiliki pendidiknya. Dalam kondisi tersebut, maka kemampuan anak didik dalam berpikir kreatif di kelas kurang berkembang.

Ditinjau dari pernyataan sebelumnya, maka model pemetaan pikiran dapat dijadikan sebuah solusi pemecahannya. Model pemetaan pikiran merupakan sebuah model pembelajaran kooperatif yang diperkenalkan oleh Toni Buzan. pemetaan pikiran adalah sebuah cara menulis materi yang diajarkan untuk mempermudah anak didik pada saat belajar. pemetaan pikiran dapat digolongkan sebagai teknik menulis kreatif. Digolongkan dalam teknik kreatif karena dalam membuat pemetaan pikiran membutuhkan penggunaan imajinasi dari penciptanya. Hal tersebut selaras dengan pendapat Carolina et al. (2016) bahwa pemetaan pikiran adalah sebuah teknik menulis materi yang dipelajari dan memprediksi permasalahan yang dihadapi dalam bentuk grafik sehingga mempermudah memahaminya. Model pemetaan pikiran mampu mendorong kemampuan dari otak bagian kiri dan otak bagian kanan dengan memaparkan prihal yang bersifat umum kemudian baru ke prihal yang bersifat khusus dalam sebuah grafik. Otak yang menyerap berbagai informasi seperti gambar, simbol dan warna adalah fungsi kerja dari otak bagian kanan atau berhubungan dengan pemikiran kreatif (Olivia, 2014).Model pemetaan pikiran memiliki 6 tahapan pelaksanaan. keenam tahapan tersebut adalah pendidik menjelaskan tujuan pembelajaran yang mau dicapai, pendidik menjelaskan materi, anak didik terbagi dalam beberapa kelompok beranggotakan 2 orang, anak didik membuat peta pikiran, siswa mempresentasikan hasil peta pikiran secara berkelompok, kesimpulan (Shoimin, 2014).

Terdapat beberapa penelitian sebelumnya yang menggunakan model pemetaan pikiran dan kemampuan dalam berpikir kreatif. Pada penelitian (Mirna, 2014) meperlihatkan bahwa pembelajaran menggunakan tugas pembuatan peta pikiran pemahaman siswa menjadi lebih unggul atau dapat dikatakan meningkatnya kemampuan anak didik dalam berpikir kreatif. Kemudian pada penelitian (Yanti, Sudia \& Arapu, 2019) menerangkan bahwa terdapat pengaruh pelaksanaan model pemetaan pikiran terhadap kemampuan anak didik dalam berpikir matematis. Hal itu selaras dengan hasil penelitian dari (Darussman, 2014) yang memperlihatkan bahwa terdapat adanya pengaruh pemetaan pikiran terhadap kemampuan anak didik dalam berpikir kreatif.

Hasil observasi yang dilaksanakan di SMPN 1 Pagelaran dengan mewawancarai guru IPS kelas 7 kedapatan bahwa model pembelajaran yang diterapkan oleh pendidik adalah model pembelajaran konvensional yang berisikan metode seperti ceramah yang dilengkapi dengan kegiatan tanya jawab. Siswa masih sering melaksanakan kegiatan mendengarkan dan mencatat selama pembelajaran berlangsung. Padahal agar tujuan pembeajaran itu tercapai tidak cukup hanya dengan menerapkan model konvensional. Guru kurang memberdayakan model-model pembelajaran lainnya yang dapat membuat kemampuan anak didik dalam berpikir kreatif menjadi berkembang. 
Sehingga siswa cenderung terbiasa mengandalkan pengetahuan sepenuhnya dari pendidik dan buku teks, bukan mengkonstruksi sendiri pengetahuannya dari pemahaman atau pemikiran originalnya. Anak didik kurang terangsang dalam berpikir berbeda yang lebih mencerminkan kemampuan kreatif, sebab pemikiran divergen mengarah pada memungkinkan beragamnya jawaban terhadap sebuah persoalan. Lebih lanjut diperoleh keterangan bahwa pembelajaran menggunakan model pemetaan pikiran sama sekali belum pernah diterapkan pada materi kelangkaan di kelas.

Materi kelangkaan dalam pelajaran pengetahuan sosial adalah materi yang wajib ditempuh oleh anak didik kelas VII. Dalam materi pokok mengenai kelangkaan terdapat beberapa masalah yang wajib diatasi oleh siswa. selaras dengan penerapan model pemetaan pikiran yaitu untuk teknik menulis materi yang dipelajari dan memprediksi permasalahan yang dihadapi dalam bentuk grafik sehingga mempermudah memahaminya. (Sugiarto, 2004). Dari penelitian (Mirna, 2014; Yanti, Sudia \& Arapu, 2019; Darussman, 2014; Acesta, 2020) yang memperlihatkan bahwa model pemetaan pikiran berpengaruh terhadap kemampuan anak didik dalam berpikir kreatif matematis, sehingga perlu adanya lanjutan mengenai penerapan model pemetaan pikiran terhadap kemampuan anak didik dalam berpikir kreatif pada mata pelajaran dan materi ajar yang berbeda. Oleh sebab itu, dalam pembelajaran materi kelangkaan pada pelajaran Pengetahuan Sosial kelas VII dengan menerapkan model pemetaan pikiran untuk meningkatkan kemampuan anak didik dalam berpikir kreatif.

\section{METODE}

Penelitian ini mempunyai tujuan yaitu melihat pengaruh model pemetaan pikiran terhadap kemampuan anak didik dalam berpikir kreatif. Pengaruhnya dapat dilihat dengan cara membandingkan kemampuan anak didik dalam berpikir kreatif pada kelas yang menngunakan model pemetaan pikiran dan kelas yang menerapkan model konvensional . Penelitian tersebut dikerjakan dengan menerapkan metode kuasi eksperimen. Dalam penelitian tersebut diambil sampel 2 kelas dengan pembelajaran berbeda. Kelompok pertama, diberikan pembelajaran model pemetaan pikiran(X), sebaliknya kelompok kedua sebagai kelompok pembanding menerapkan pembelajaran dengan model konvensional.

Penelitian ini diberlakukan pada anak didik kelas kelas VII di SMPN 1 Pagelaran. Populasi pada penelitian ini adalah semua siswa kelas VII di SMPN 1 Pagelaran yang berjumlah 6 kelas. Pada penelitian tersebut diambil 2 kelas yang merupakan sampel penelitian, yang terdiri dari kelas yang menngunakan model pemetaan pikiran dan kelas yang menerapkan model konvensional. Kelas VII-A sebagai kelas yang menggunakan model pemetaan pikiran, sedangkan kelas VII-B sebagai kelas yang mendapatkan pembelajaran yang konvensional. Semua kelas itu dijadikan sebagai sampel karena menurut pertimbangan guru sosial, 2 kelas itu mempunyai kemampuan yang relatif sama. Berikut demografi pada sampel penelitian:

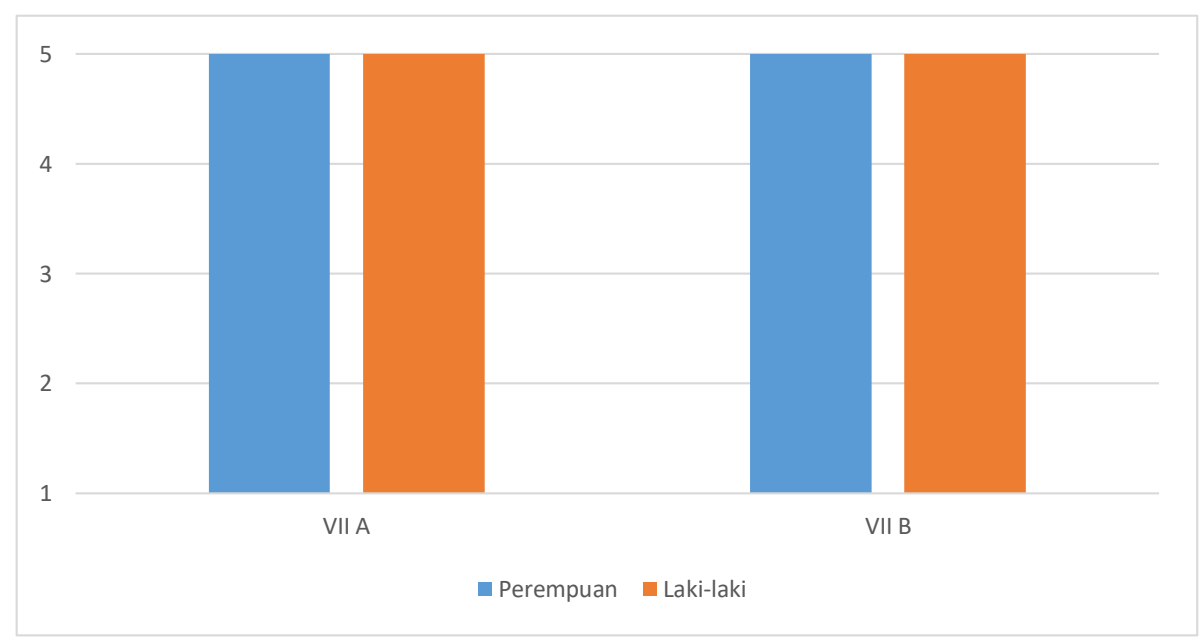

Gambar 1. Demografi Sampel Penelitian

Dalam kelas VII A yang merupakan kelas yang menerapkan model pemetaan pikiran terdapat siswa berjumlah 10 yang diantaranya terdapat 5 orang berjenis perempuan dan 5 orang dengan jenis 
kelamin laki-laki. Kemudian, siswa yang berada di kelas VII B yang merupakan kelas yang menerapkan model konvensional, dimana siswa dalam kelas tersebut berjumlah 10 orang diantaranya 5 orang dengan jenis kelamin perempuan dan 5 orang dengan jenis kelamin laki-laki.

Tahapan penelitian yaitu tahap persiapan (membuat kisi-kisi tes, membuat instrumen tes kemampuan siswa dalam berpikir kreatif berupa soal berbentuk uraian dan selanjutnya menguji instrumen tes tersebut yang berisi materi kelangkaan pada siswa yang sudah menempuh pembelajaran materi kelangkaan yang selanjutnya diuji validitas serta reliabilitas soal yang sudah diujicobakan, membuat RPP, dan bahan ajar), tahap pelaksanaan (melaksanakan pembelajaran materi kelangkaan, untuk kelas yang menerapkan model pemetaan pikiran dan kelas yang menerapkan pembelajaran yang konvensional, memberikan post-test setelah pembelajaran pada kedua kelas yang telah diuji coba yakni kelas 7A dan kelas 7B, tahap penyelesaian (mengumpulkan data dari hasil tes masing-masing kelas, mengolah dan menganalisa data, data dari hasil analisis diinterpretasikan lalu dapat menyimpulkan berdasarkan pada hipotesis dan rumusan masalah). Indikator berpikir keratif yaitu Fluency (berpikir lancar), Flexibility (kelenturan), Elaboration (elaborasi), Originality (keaslian) dengan setiap indikator berisikan 2 soal kemampuan siswa dalam berpikir kreatif.

Sebelum data dianalisis, data wajib berdistribusi normal sehingga data yang dihasilkan harus melewati uji normalitas terlebih dahulu. Kemudian setelahnya, melakukan uji homogenitas guna melihat data pada setiap kelas memiliki varian sama atau berbeda. Perhitungan semua uji menggunakan SPSS 20.

\section{HASIL}

Perolehan hasil nilai post test kemampuan siswa dalam berpikir berpikir kreatif pada kelompok yang menerapkan model pemetaan pikiran dan kelompok yang menerapakan model yang konvensional dari penelitian yang sudah dilakukan tersaji pada tabel 1 .

Tabel 1. Statistik Deskriptif

\begin{tabular}{ccccccc}
\hline Kelompok & N & $\begin{array}{c}\text { Minimum } \\
\text { Statistic }\end{array}$ & $\begin{array}{c}\text { Maximum } \\
\text { Statistic }\end{array}$ & Mean & Std. Deviation & Variance Statistic \\
\hline Nilai Kelas Eksperimen & 10 & 56 & 97 & 82,3 & 12,35 & 151,7 \\
Nilai Kelas Kontrol & 10 & 50 & 88 & 70,2 & 12,65 & 160,1 \\
\hline
\end{tabular}

Data tabel 1 menunjukkan rata-rata pada nilai dari post test kemampuan siswa dalam berpikir kreatif kelas yang menerapan yaitu 82,3 dengan standar deviasi 12,35 dan varian 151,7. Sedangkan rata-rata pada nilai dari post test kemampuan siswa dalam berpikir kreatif kelas yang menggunakan model yang konvensional yaitu 70,2 dengan standar deviasi 12,65 dan varian 160,1. Hal ini berarti kemampuan anak didik dalam berpikir kreatif kelas yang menerapkan model pemetaan pikiran lebih besar dibandingkan dengan kelas yang menerapkan model yang konvensional.

\section{Uji Normalitas}

Masing-masing yang dihasilkan dari setiap kelas dengan melakukan uji normalitas guna untuk melihat hasil tes yang dihasilkan oleh setiap kelas datanya berdistribusi normal atau tidaknya. Uji yang digunakan yaitu uji Shapiro-Wilk, karena sampel $<50$ orang.

Tabel 2. Uji Normalitas

Shapiro-Wilks Test

\begin{tabular}{cccc}
\hline Kelas & Statistic & df & Sig. \\
\hline Eksperimen & 0,927 & 10 & 0,415 \\
Kontrol & 0,937 & 10 & 0,516 \\
\hline
\end{tabular}

Pada data tabel 2 diperlihatkan perolehan analisis uji coba normalitas pada kelas yang menerapkan model pemetaan pikian dan kelas yang menerapkan model yang konvensional. Pada kelas eksperimen terdapat 10 siswa sebagai subyek penelitian dengan nilai Sig. sebesar 
0,415. Sedangkan pada kelas kontrol terdapat 10 siswa sebagai subyek penelitian dengan Sig. sebesar 0,516. Maka selaras dengan kriteria yang sudah ditentukan, kalau nilai probabilitas lebih besar dari 0,05 maka data tersebut dapat dikatakan berdistribusi normal. Pada uji normalitas pada kelas eksperimen dan kelas kontrol yang sudah dilakukan menunjukkan data dari hasil post test berdistribusi normal dikarenakan nilai probabilitas lebih besar dari 0,05

\section{Uji Homogenitas}

Uji homogenitas menerapkan uji Test of Homogeneity of Variances. Adapun kriteria data, apabila data yang dihasilkan >0,05 maka data itu bisa dikatakan sebagai data yang homogen. Berikut perolehan perhitungan menggunakan SPSS 20.

Tabel 3. Uji Homogenitas

\begin{tabular}{cccc}
\hline Levene Statistic & df1 & df2 & Sig. \\
\hline 0,005 & 1 & 18 & 0,943 \\
\hline
\end{tabular}

Dari tabel 3 nilai signifikansi memperoleh nilai sebesar 0,943>0,05. Sehingga data yang dihasilkan bersifat homogen atau memiliki varian yang sama.

\section{Uji Hipotesis}

Teknik analisis Independent Sample T-Test digunakan sebagai uji hipotesis. Uji tersebut digunakan untuk mengetahui data yang dihasilkan dari VII A (kelas eksperimen) dan VII B (kelas kontrol) memiliki perbedaan pada hasil kemampuan siswa dalam berpikir kreatifnya. Pengujian didasarkan pada hipotesis.

Tabel 4. Independent Sample T-Test

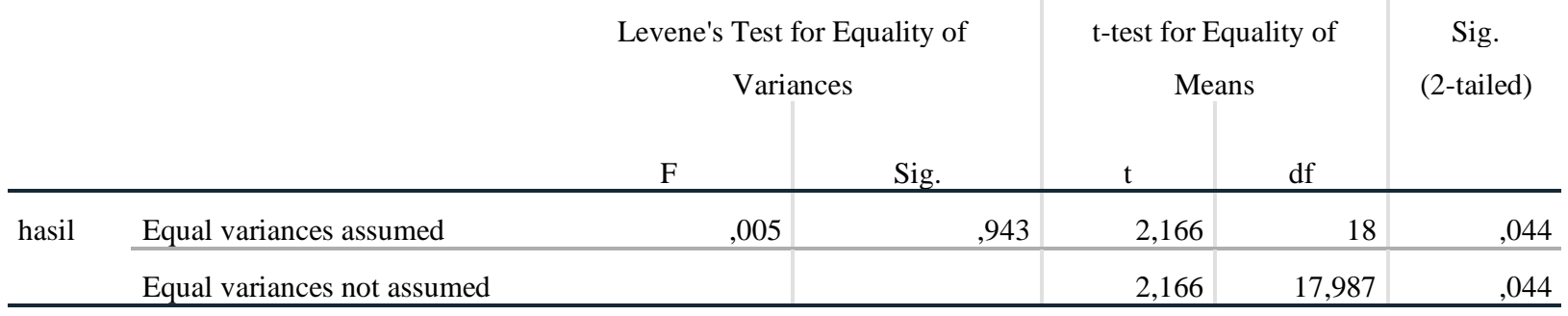

Dari tabel 4 menunjukkan nilai signifikansi dengan equal variance assumed (diasumsikan kedua varian sama) adalah 0,044 lebih kecil dari 0,05 maka $\mathrm{H}_{0}$ ditolak. Hal itu memperlihatkan hipotesis yaitu terdapat adanya perbedaan yang signifikan terhadap kemampuan berpikir kreatif antara anak didik yang menerapkan model pembelajaran pemetaan pikiran dengan siswa yang menerapkan model yang konvensional dalam mata pelajaran IPS.

\section{PEMBAHASAN}

Hasil post test kemampuan anak didik dalam berpikir kreatif yang menerapkan model pemetaan pikiran (kelompok eksperimen) memiliki rata-rata sebesar 82,30. Nilai tersebut apabila dikategorikan menurut tabel kriteria penilaian Arikunto (2010) termasuk golongan sangat baik. Model pemetaan pikiran pebelajar lebih meningkatkan kegunaan otak dengan memciptakan materi ajar terpola dengan visual dan grafis yang akhirnya bisat mempermudah merekam, dan meningkatkan materi yang udah dipelajari sebelumnya. Otak yang bisa menangkap informasi seperti gambar, simbol, warna adalah kegunaan otak bagian kanan atau yang berhubungan terhadap pemikiran kreatif. Hal ini selaras terhadap tujuan utama dari model pemetaan pikiran yaitu menciptakan materi ajar yang terpola berupa visual dan grafis yang akhirnya dapat mempermudah merekam, dan mengingat materi yang telah dipelajari 
sebelumnya (Jensen \& Makowitz, 2002). Hal itu mendukung faktor yang bisa mempengaruhi kemampuan anak didik dalam berpikr kreatif.

Penerapan model pemetaan pikiran pertemuan pertama pada kelas 7A(kelas eksperimen) dengan materi kelangkaan. Dalam tahap pertama siswa diberikan motivasi belajar dengan pemberian pertanyaan berupa gambar terkait kelangkaan pada kehidupan keseharianya. Kemudian dilanjutkan dengan pemberitahuan tujuan pembelajaran tersebut. Sedangkan di tahap pemberian materi siswa diberikan berbagai sumber belajar untuk dipelajari oleh siswa dan sedikit penjelasan yang dilakukan oleh pendidik terkait materi kelangkaan. setelah pemberian materi, dilanjutkan dengan guru memberikan sebuah sebuah masalah mengenai kelangkaan yang bisa dipecahkan oleh setiap siswa, dan panduan untuk menjawab masalah tersebut telah tersedia dalam materi pembelajaran. Di tahap terakhir dalam pertemuan pertama siswa memberikan kesimpulan terkait pembelajaran pada hari tersebut dan guru menutup pembelajaran kemudian memerintahkan anak didik untuk mengunduh aplikasi pemetaan pikiran yang tersedia di smartphone untuk mengganti peralatan manual seperti kertas dan spidol warna karena pembelajaran dikerjakan secara online.

Pada pertemuan kedua pebelajar dibagi menjadi beberapa kelompok yang berisikan 2 orang. Tahap berikutnya siswa membaca petunjuk pembuatan pemetaan pikiran dan melihat video tutorial contoh pembuatan pemetaan pikiran dengan aplikasi yangsudah tersedia di smartphone. Dalam tahap siswa membuat pemetaan pikiran guru berguna sebagai fasilitator yaitu dengan memberikan bimbingan dan bantuan pada anak didik yang mengalami kesulitan ketika membuat pemetaan pikiran. Di tahap terakhir siswa diperintahkan untuk mempresentasikan hasil peta pikiran yang telah dibuat sebelumnya. Dalam tahap ini pebelajar serta guru memberikan apresiasi dan masukan terhadap hasil peta pikiran yang telah dibuat setiap kelompok.

Menurut Munandar (2012) kreativitas yaitu sebuah proses merasakan dan melihat ada tidaknya permasalahan, menciptakan hipotesis mengenai kelemahan (masalah) tersebut, menilai serta menguji hipotesis, lalu merubah serta mengujinya lagi, dan terakhir disampaikan hasil-hasilnya. Hal ini sebanding dengan penelitian Jampel \& Widiana (2016) menyatakan bahwa Pendekatan pembelajaran peta pikiran dapat memberikan peningkatan pada keterampilan berpikir kreatif siswa. Hal ini sejalan juga dengan pendapat Carolina et al. (2004) bahwa pemetaan pikiran adalah sebuah teknik menulis materi yang dipelajari dan memprediksi permasalahan yang dihadapi dalam bentuk grafik sehingga mempermudah memahaminya. Pemetaan Pikiran bisa difungsikan untuk menghasilkan, memvisualisasikan, mengatur, mencatat, memecahkan sebuah permasalahan, membuat keputusan, merevisi dan mengklarifikasi topik (Arulselvi, 2017). Penjelasan diatas sesuai dengan penerapan yang diterapkan pada kelas yang diterapkannya peta pikiran yaitu siswa diberikan masalah terkait materi untuk diamati dan diselesaikan berupa mind map agar bisa dimengerti.

Kreativitas dan inovasi bisa bertambah berkembang jika siswa mempunyai kesempatan unik untuk menggunakan pemikiran divergen. Siswa harus berpikir tidak seperti kebiasaannya, melibatkan cara berpikir baru, memperoleh kesempatan dalam mengkomunikasikan ide dan solusi baru, mengajukan pertanyaan yang tidak umum, dan mencoba memberikan jawaban yang diasumsikan (Ndiung, 2019). Sedangkan menurut La Moma (2012) yaitu berpikir dengan kreatif adalah suatu keterampilan berpikir dengan diawali adanya kepekaan melihat situasi yang dihadapinya, bahwa situasi tersebut terdapat sebuah masalah yang wajib diatasi. Oleh karena hal itu jawaban yang diperoleh pebelajar pada saat mengerjakan tes beragam, dan banyak memperoleh gagasan baru sejalan dengan indikator tes. Kemampuan berpikir yang kreatif terdapat beberapa indikator wajib dipenuhi, seperti berpikir orisinal, berfikir detail, berpikir lancar, berfikir fleksibel (Maskur et al., 2019).

Model peta pikiran lebih berpusat pada pebelajar. Hal tersebut membuat pebelajar diberi sebuah kebebasan dalam mencerna ide atau konsep siswa itu sendiri sehingga mudah untuk dipahami. Peta pikiran membantu pebelajar mempelajari informasi dengan menambahkan gambar serta warna Petapeta ini telah terbukti menurunkan beban kognitif ekstrinsik karena siswa menciptakan ruang dua 
dimensi untuk mengikat ide dan konsep yang saling berhubungan. Peta pikiran memberikan pebelajar unutk menciptakan gambar visual untuk mengoptimalkan pembelajaran dan bisa dipergunakan sebagai alat metakognitif yang memungkinkan untuk menciptakan koneksi ke materi dengan upaya yang bermakna (Brett, 2012). Penggunaan peta pikiran sebagai alat pembelajaran karena otak lebih dipermudah menerima dan memahami peta pikiran unutk merangsang secara visual, multi-warna, multidimensi, daripada catatan liner yang membosankan (Prabha \& Aziz, 2020). Dalam pemetaan pikiran, kata-kata diganti dengan grafik singkat dan bagus yang mudah diingat dan menyerupai kegunaan otak manusia. Pemetaan pikiran bergantung pada menggambar diagram atau bagan yang sejalan dengan cara pikiran memproses informasi (Bawaneh, 2019). Diagram gambar dan struktur dianggap lebih dapat dipahami dari pada hanya kata-kata, dan upaya yang tepat untuk menggambarkan pemahaman tentang topik yang kompleks (Gargouri \& Naatus, 2017). Menggunakan gambar, ikon, tag, dan visual lainnya sebagai film video dalam kasus pemetaan pikiran terkomputerisasi berguna karena membantu mengasosiasikan ide dengan upaya yang menarik (Sabbah, 2015).

Hasil dari post test kemampuan pebelajar dalam berpikir yang kreatif yang menerapkan model yang konvensional mempunyai mean nilai 70,20. Rata-rata tersebut lebih rendah dari pada rata-rata kelas eksperimen. Kemampuan berpikir yang kreatif kelas 7 B (kelas kontrol) lebih rendah dari pada kelas 7 A (kelas eksperimen) apabila diamati melalui nilai mean hasil post test kemampuan berpikir yang kreatif. Mean nilai kelas yang menerapkan model yang konvensional tergolong baik.

Pembelajaran yang konvensional lebih mengoptimalkan pada resitasi konten, tanpa tersedianya waktu yang cukup pada pebelajar dalam mencerna materi yang dipaparkan, menghubungkan dengan pengetahuan yang diperoleh sebelumnya, atau menerapkan pada kondisi kehidupan nyata saat ini (Burrowes, 2003). Model pembelajaran yang konvensional tidak berpusat pada pebelajaran. Hal tersebut membuat siswa tidak diberi kebebasan untuk mengkonstruksi ide atau konsep siswa sendiri sehingga tidak mudah untuk dipahami dan tidak semua siswa memiliki cara belajar terbaik dengan mendengarkan. Siswa sering mengalami kesulitan untuk menjaga agar tetap tertarik dengan apa yang dipelajari dan cenderung membuat bosan. Hal tersebut membuat kemampuan berpikir kreatif siswa tidak berkembang.

Dari pembahasan sebelumnya, dapat diperoleh bahwa Ho ditolak yang artinya Ha dapat diterima atau dengan kata lain terdapat sebuah perbedaan yang signifikan terhadap kemampuan berpikir yang kreatif antara anak didik yang menggunakan model pemetaan pikiran dengan anak didik yang menggunakan model yang konvensional pada mata pelajaran IPS. Hal tersebut, selaras terhadap penelitian sebelumnya bahwa terdapat adanya pengaruh model pemetaan pikiran terhadap kemampuan anak didik yang berpikir kreatif (Acesta, 2020; Rahayu, Akbar \& Afrilianto, 2019; Siswanto \& Awalludin, 2018; Arriah, 2019; Priantini, Atmadja \& Marhaeni, 2013). Kemudian, hasil penelitian yang sebelumnya menyatakan bahwa diterapkannya model pemetaan pikiran mampu mengoptimalkan kemampuan anak didik dalam berpikir kreatif (Darusman, 2014; Hidayat et al., 2020; Sulistiyono, Mahanal \& Murni saptasari, 2017; Sarmi, 2020; Wulandari, Mawardi \& Wardani, 2019. Jadi dapat diperoleh yaitu hipotesis "ada perbedaan yang signifikan terhadap kemampuan anak didik dalam berpikir yang kreatif antara yang menggunakan model pembelajaran pemetaan pikiran dengan pebelajar yang menggunakan model yang konvensional pada mata pelajaran IPS" telah terbukti.

\section{SIMPULAN}

Model Mind Mapping dapat membantu dalam memproyeksikan masalah yang dihadapi ke dalam bentuk peta atau teknik grafik sehingga lebih mudah memahaminya dengan teknik mencatat/meringkas bahan yang dipelajari. Model pembelajaran mind mapping lebih berpusat pada siswa. Hal tersebut membuat siswa diberi kebebasan untuk mengkonstruksi ide atau konsep siswa sendiri sehingga mudah untuk dipahami dan membantu meningkatkan kemampuan berpikir kreatifnya. Berdasarkan dari pengelolaan dan analisis data untuk melakukan hipotesis, dapat diperoleh bahwa terdapat perbedaan yang signifikan kemampuan berpikir kreatif antara siswa yang menggunakan model pembelajaran mind mapping dengan siswa yang menggunakan model pembelajaran konvensional. 
Untuk Tenaga pendidik diharapkan menerapkan model mind mapping yang menunjang kemampuan berpikir kreatif siswa. Diharapkan bagi penelitian selanjutnya dengan permasalahan sejenis, dapat dilakukan lebih mendalam dan menerapkan model pembelajaran eksperimen dalam jangka waktu yang lebih lama.

\section{DAFTAR RUJUKAN}

Acesta, A. (2020). Pengaruh penerapan metode mind mapping terhadap kemampuan berpikir kreatif siswa. Jurnal Kajian Penelitian dan Pendidikan dan Pembelajaran. 4(2), 581-586.

Arulselvi, E. (2017). Mind Maps in Classroom Teaching and Learning. The Excellence in Education Journal. 6(2).

Arriah, F. (2019). Pengaruh penerapan metode pembelajaran mind mapping terhadap kemampuan berpikir kreatif matematika. Jurnal Ilmiah Prodi Pendidikan Matematika FKIP Unismuh Makassar. 11(2).

Bawaneh, A. K. (2019). The effectiveness of Using Mind Mapping on Tenth Grade Students' Immediate Achievement and Retention of Electric Energy Concepts. Turkish Science Education. 16(1).

Buzan,T. (2011). What Is Mind Map. [Online]. (Diakses Melalui Http://Www.TonyBuzan.Com/About/Mind-Mapping/ Pada Tanggal 10 Mei 2020).

Brett, D. J., Ruff, C., Snyder, J. D., Petrich, B., \& Koonce, C. (2012). The Effects of Mind Mapping Activities on Students' Motivation. The Scholarship of Teaching and Learning. 6(1).

Carolina, S. A., Yaya, S. K., Jozua, S., \& Jarnawi, A. D. (2016). The Enhancement of Mathematical Reasoning Ability of Junior High School Students by Applying Mind Mapping Strategy. Education and Practice. 7(25).

Darusman, R. (2014). Penerapan metode mind mapping (peta pikiran) untuk meningkatkan kemampuan berpikir kreatif matematik siswa SMP. Jurnal Ilmiah Program Studi Matematika STKIP Siliwangi Bandung. 3(2).

Gargouri, C., \& Naatus, K. M. (2017). An experiment in mind-mapping and argument mapping: Tools for assessing outcomes in the business curriculum. Business Education \& Scholarship of Teaching. 11(2), 39-78.

Hidayat, H. dkk. (2020). Penerapan metode mind mapping untuk meningkatkan kreativitas pada pembelajaran pendidikan kewarganegaraan. Jurnal Pendidikan. 21(1), 38-50.

La Moma. (2013). Menumbuhkan Kemampuan Berpikir Kreatif Matematis Melalui

Pembelajaran Generatif Siswa Smp. Prosiding. Seminar Nasional Matematika Dan Pendidikan Matematika.

Maskur, R. dkk. (2019). The Effectiveness of Problem Based Learning and Aptitude Treatment Interaction in Improving Mathematical Creative Thinking Skills on Curriculum 2013. Educational Research. I9(1), 375-388.

Mirna. (2014). Pengaruh Mind Map Terhadap Kemampuan Berpikir Kreatif Siswa Dalam Pembelajaran Matematika Di Kelas VII SMP Negeri 8 Padang, Jurnal Pendidikan. 2 (7).

Munandar, Utami. (2012). Pengembangan Kreativitas Anak Berbakat. Jakarta:Rineka Cipta.

Ndiung, S., Dantes, N., Ardana, I. M., \& Marhaeni, A. A. I. N. (2019). Treffinger Creative Learning Model with RME Principles on Creative Thinking Skill by Considering Numerical Ability. Instruction. 12(3).

Olivia, Femi. (2014).5-7 Menit Asyik Mind Mapping Kreatif. Jakarta : PT.Gramedia. 
Prabha, T., \& Aziz, A. A. (2020). Effectiveness of Using Poly Category Mind Map for Vocabulary Development. Arab World English Journal. 11(2), 214-231.

Priantini, D. A. M. M. O., Atmadja, N. B., \& Marhaeni, A. A. I. N. (2013). Pengaruh metode mind mapping terhadap keterampilan berpikir kreatif dan prestasi belajar IPS. Journal Program Pascasarjana Universitas Pendidikan Ganesha Jurusan Pendidikan Dasar. Vol 3.

Rahayu, E. L., Akbar, P., \& Afrilianto, M. (2019). Pengaruh metode mind mapping terhadap strategi thinking aloud pair problem solving terhadap kemampuan berpikir kreatif matematis. Journal On Education. 1(2), 271-278.

Sarmi. (2020). Penggunaan model pembelajaran mind mapping untuk meningkatkan kreativitas dan penguasaan materi pelajaran ekonomi. Jurnal Kajian Teknologi Pendidikan. 3(1), 78-87.

Sabbah, S. S. (2015). The effect of college students' self-generated computerized mind mapping on their reading achievement. Education and Development using Information and Communication Technology. 11(3), 4-36.

Shoimin, Aris. (2014). 68 Model Pembelajaran Inovatif Dalam Kurikulum 2013. Yogyakarta: Ar-Ruzz Media.

Siswanto, R. D., \& Awalludin, S. A. (2018). Pengaruh pembelajaran dengan menggunakan mind map terhadap kemampuan berpikir kreatif matematis siswa. Seminar Nasional Pendidikan Matematika. Vol. 1.

Sulistiyanto, E., Mahanal, S., \& Saptasari, M. (2017). Peningkatan keterampilan berpikir kreatif dan hasil belajar kognitif melalui pembelajaran biologi berbasis speed reading-mind mapping (SRMM). Jurnal Pendidikan. 2(9), 1226-1230.

Widiana, I. W., \& Jampel, I. W. (2016). Improving Students' Creative Thinking and Achievement through The Implementation of Multiple Intelligence Approach with Mind Mapping. Evaluation and Research in Education. 5(3), 246-254.

Wulandari, F. A., Mawardi, \& Wardani, K. W. (2019). Peningkatan Keterampilan Berpikir Kreatif Siswa Kelas 5 Menggunakan Model Mind Mapping. Jurnal Ilmiah Sekolah Dasar. 3(1), 10-16.

Yanti, Sudia \& Arapu. (2019). Pengaruh Model Pembelajaran Mind Mapping Terhadap Kemampuan Berpikir Kreatif Matematis Peserta Didik Kelas VIII SMP Negeri 8 Konawe Selatan, Jurnal Pendidikan. 7 (3). 